\title{
Identification and Analysis Coral Reefs Changes Using Landsat 8 OLI Imagery in Coastal Zone of Langsa City
}

\author{
Muhammad Taufik Rahmadi ${ }^{1}$, Ayu Suciani ${ }^{1}$ \\ \{taufikrahmadi14@unsam.ac.id, ayusuciani@unsam.ac.id\} \\ ${ }^{1,2}$ Geography Education Department, Samudra University, Langsa, Indonesia
}

\begin{abstract}
This study aims to examine the accuracy of Landsat 8 OLI imagery in mapping spatial distribution, analyzing changes in the area, and factors that affect coral reefs changes in the coastal areas of Langsa City in 2014, 2016, and 2018. The classification methods used in this study are the multispectral classification of parallelepiped algorithms and field surveys using the photo transect method. The results of this study are (1) the level of accuracy of Landsat 8 OLI imagery for the mapping of coral reefs on the coast of Langsa City is $42.50 \%$; (2) the coral reef in the coast of Langsa City has increased 1,372.77 Ha in 2014-2016 and decrease1,386 Ha in 2016-2018, (3) the dominant factor affecting these changes was the water temperatures above the average of $34.14^{\circ} \mathrm{C}$, while dissolved oxygen levels, water $\mathrm{pH}$, and salinity is at a limit that can still be tolerated by coral reefs.
\end{abstract}

Keywords: Landsat 8 OLI, coral reefs, changes factor, Langsa

\section{Introduction}

Indonesia is one of the countries with the longest coastline in the world, which is 81.000 $\mathrm{km}$. This long coastline makes Indonesia a country that has abundant maritime resource potential that can be utilized as a source of sustainable development. Until now, the potential of Indonesia's maritime resources has not been maximally utilized, this is caused by various factors; natural factors, human factors, and artificial factors (lack of adequate technology). Potential maritime resources consist of resources that can be recovered, resources that cannot be recovered, and environmental services.

One of the resources that can be recovered and can be managed to support human life is the coral reef ecosystem. Coral reefs are shallow marine organisms whose organic productivity is very high compared to other organisms found on the bottom of shallow waters and grows well in tropical regions (Nyabakken, 2001). Coral reefs have an ecological function as a nutrient provider for aquatic biota, physical protection, spawning sites, and growth sites for a variety of biota that lives on the water bottom.

Coral reefs are ecosystems that are very vulnerable to change due to various sustainability factors such as temperature, sedimentation, $\mathrm{pH}$, and human activities. These factors make the coral reefs degrade to reach conditions that do not allow it to restore its condition naturally. Changes in coral reefs associated with changes in the structure and function of these coral reefs (Rahmadi, et al., 2018). According to LIPI (2017), the condition of Indonesia's coral reefs is of high concern namely 6.39 in very good condition, $23.40 \%$ in good condition, 
$35.06 \%$ insufficient condition, and $35.15 \%$ in damaged condition. Damage to the coral reef ecosystem is very influential in other marine ecosystems, considering the growth of coral reefs is very long.

This study used remote sensing data that has the advantage of synaptic properties that discovering the object at the same time in a large area and can measure objects at different times periodically (Winarso, 2019). This study used Landsat 8 OLI image data to determine the level of image accuracy in mapping spatial distribution and change factors of coral reefs in 2014, 2016, and 2018. The year selection 2014, 2016, and 2018 based on the rapid changes of coral reefs caused by various sustainability factors. This study also aims to provide information about the potential of coral reefs in the coastal areas of Langsa City, that it can be used as recommendations for monitoring, maintaining, and managing sustainable coral reefs.

\section{Research method}

This research has been done on June 2019 - July 2019 in the Coast of Langsa City, which is located at $04^{\circ} 24^{\prime} 35.68^{\prime \prime}-04^{\circ} 33^{\prime} 47.03^{\prime \prime} \mathrm{N}$ and $97^{\circ} 53^{\prime} 14.59^{\prime \prime}-98^{\circ} 04^{\prime} 42.16^{\prime \prime} \mathrm{E}$, See Figure 1 below.

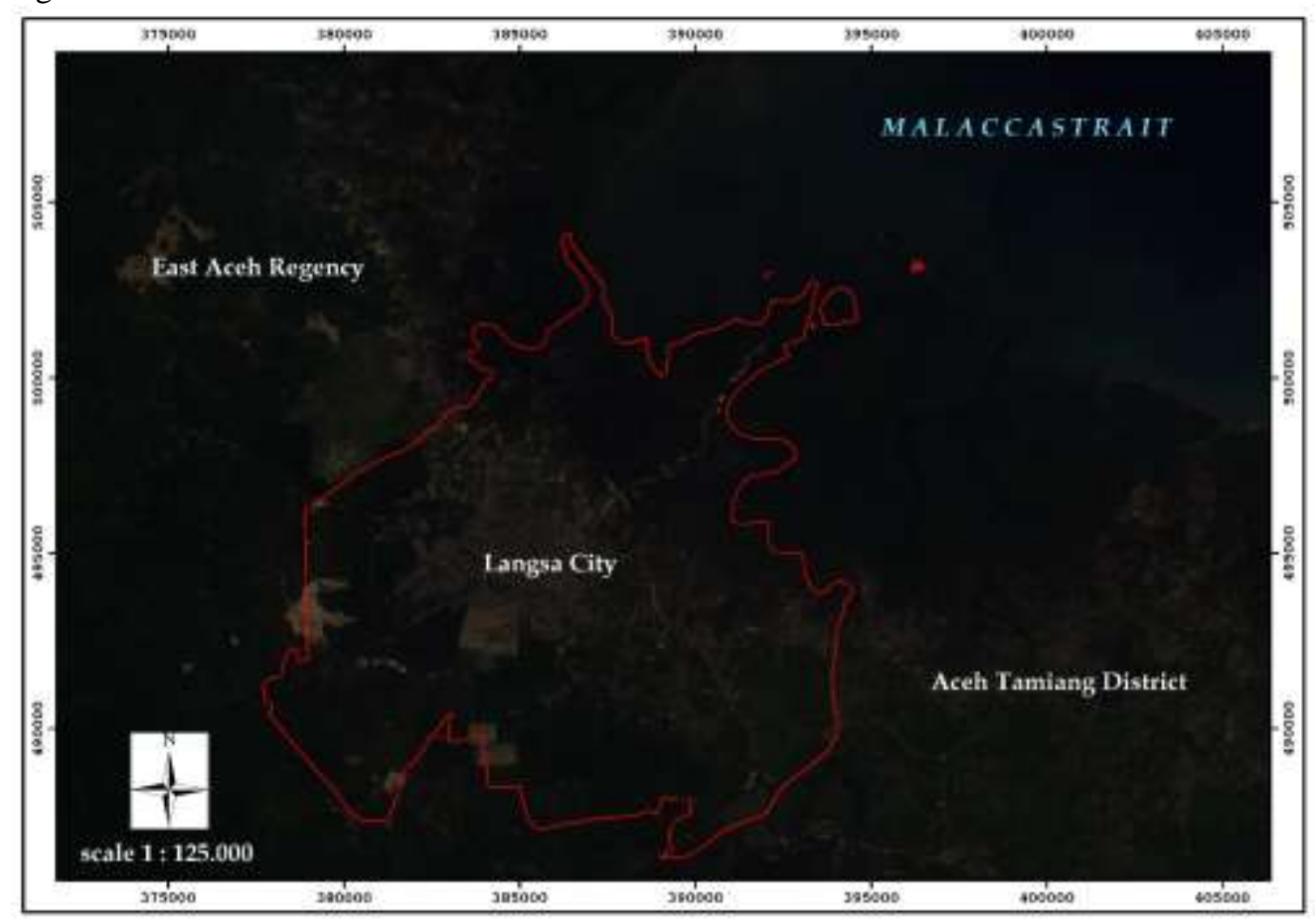

Fig. 1. Research location.

The data used in this study are Landsat 8 OLI imagery in 2014, 2016 and 2018, transect photo samples from the field, dissolved oxygen data, temperature, salinity, and water $\mathrm{pH}$. This research conducted in several stages; (1) image data processing consisting of geometric, radiometric, atmospheric, sunglint, water column (Lyzenga), and multispectral classification, 
(2) field survey using the photo transect method developed by Roelfsema et al (2009). This method records all objects at the point of sampling in the form of photographs, (3) image accuracy testing using the confusion matrix table method that connects the results of the classification that has been done (mapping) with the results from the field, and (4) image reinterpretation. The results of this test are the accuracy of Landsat 8 OLI imagery and the factors that affect changes in the size of coral reefs.

\section{Result and discussion}

The image accuracy test in this study was conducted to determine the accuracy level or accuracy of the coral reef distribution mapping. The accuracy test of this research used the confusion matrix and image of 2018. This study took 30 sample points in testing the level of image accuracy. The overall accuracy in the multispectral classification of the parallelepiped algorithm is $42.50 \%$. The low level of accuracy of Landsat 8 OLI imagery in this study was caused by several factors; the condition of the water which was slightly choppy during the field survey, errors when sampling objects and the visual quality of the image was not good due to atmospheric effects.

Mapping the distribution of coral reefs in the Coastal Areas of Langsa City in 2014, 2016, and 2018 was obtained based on the results of the multispectral classification of the parallelepiped algorithm by taking 350 ROI samples on each object. The use of a parallelepiped algorithm, it provides the best and logical classification results among other multispectral classification algorithms. The data used for this classification was the result of the water column correction (Lyzenga).

Table 1. Distribution and extent changes in coral reefs on the coast of Langsa City, 2014, 2016, and 2018.

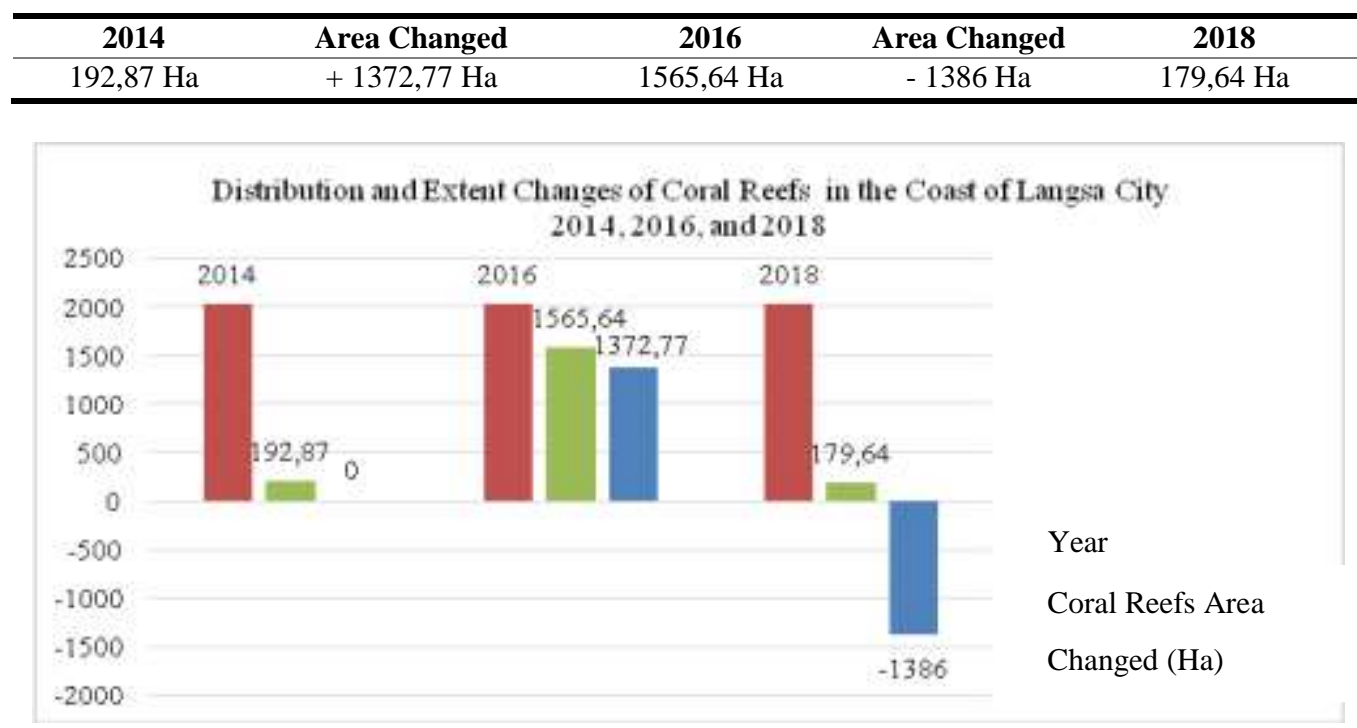

Fig. 2. The graph of distribution and extent change of Coral Reef on the coast of Langsa City 2014-2018. 

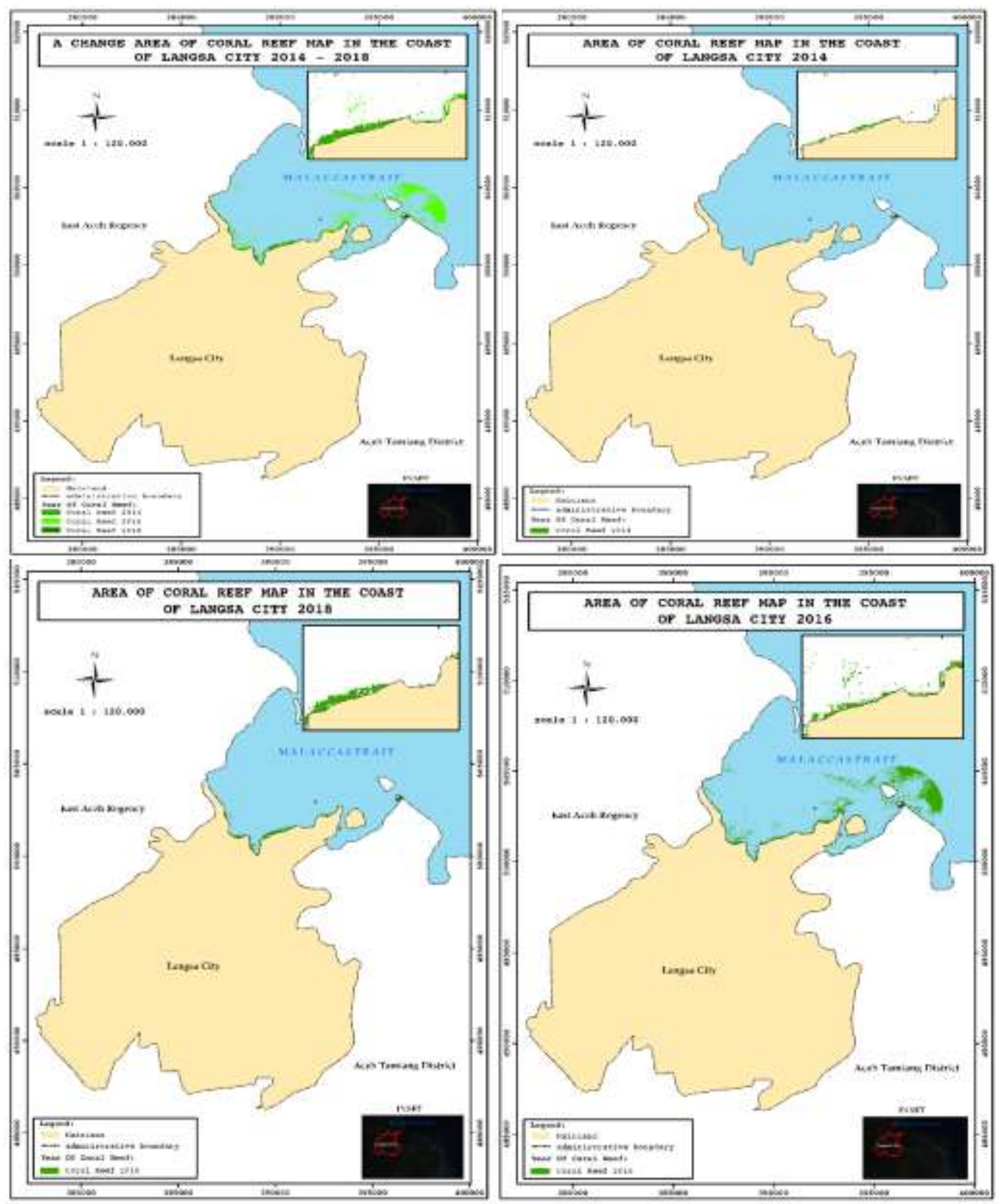

Fig. 3. Area of Coral Reefs map on the coast of Langsa City 2014, 2016 and 2018.

Figure 3 Shown the distribution area of coral reefs in the Coast of Langsa City. The distribution of coral reefs can change the structure (area increase and evolution) due to sustainability factors as natural factors (temperature, $\mathrm{pH}$, salinity, and dissolved oxygen levels) and artificial factors (human activities). Sustainability factors of coral reefs have an 
important role in the survival of coral reefs and other conservation relationships that survive on coral reefs. Sustainability factors of coral reefs are factors that influence the survival of coral reefs. Sustainability factors of coral reefs in this study consisted of water temperature, dissolved oxygen levels, water $\mathrm{pH}$, and salinity.

Temperature is one of the most important factors in the survival of marine ecosystems. Tolerable temperature for the survival of coral reefs, which ranges from $28^{\circ}-30^{\circ} \mathrm{C}$ (Kepmen $\mathrm{LH}, 2004)$. In this study, the minimum water temperature was $31.8^{\circ} \mathrm{C}$ and the maximum water temperature was $36.6^{\circ} \mathrm{C}$, while the average water temperature was $34.14^{\circ} \mathrm{C}$. The high temperature of the waters in the research location was caused by various factors; the influence of global climate change, the imbalance of energy received by the sea surface, and the heat exchange between water and the surrounding air. For more details about the temperature conditions of the study, location can be seen in Figure 4 below.

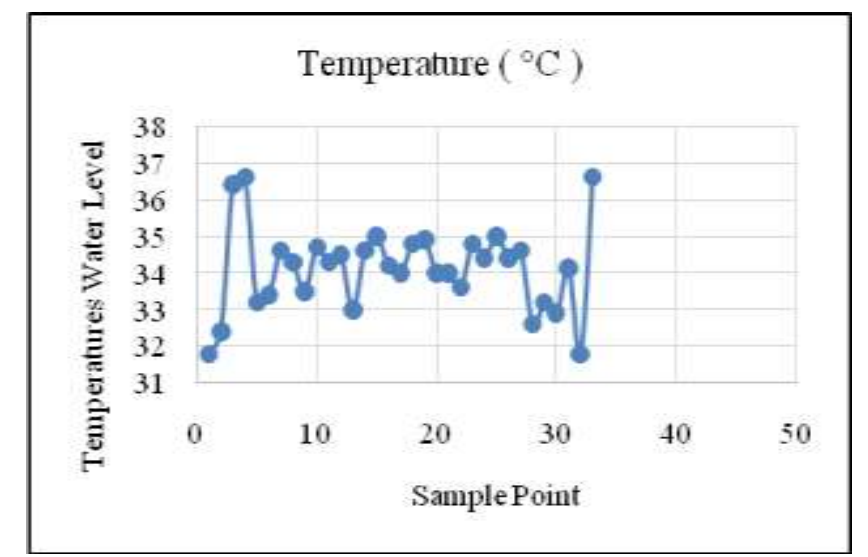

Fig. 4. Graphic of water temperature in research location.

According to Coral watch (2009) temperature changes $1^{\circ} \mathrm{C}-2^{\circ} \mathrm{C}$ put pressure on coral reefs to whiten and increase metabolism, which causes an increase in oxygen consumption and photosynthesis. One of the bad consequences of prolonged high temperatures is the phenomenon of coral bleaching and mass coral reef death. The water temperature in this study was not suitable for the conditions that can be tolerated by coral reefs.

The level of Dissolved Oxygen (DO) in water varies, depending on temperature, salinity, and atmospheric pressure. The smaller the atmospheric pressure and the greater the temperature and altitude, then the smaller the level of DO (Jeffries and Mills, 1996 in Effendi, 2003). According to McNeely et al (1979) in Effendi (2003) DO levels in ocean waters ranged from $11 \mathrm{mg} /$ liter at $0^{\circ} \mathrm{C}$ and $7 \mathrm{mg} /$ liter at $25^{\circ} \mathrm{C}$. The minimum and maximum DO levels at the research location were $4.2 \mathrm{mg} / \mathrm{liter}$ and $7 \mathrm{mg} / \mathrm{liter}$, while the average levels of DO at the research location were $5.48 \mathrm{mg} /$ liter. More details can be seen in Figure 5 below. 


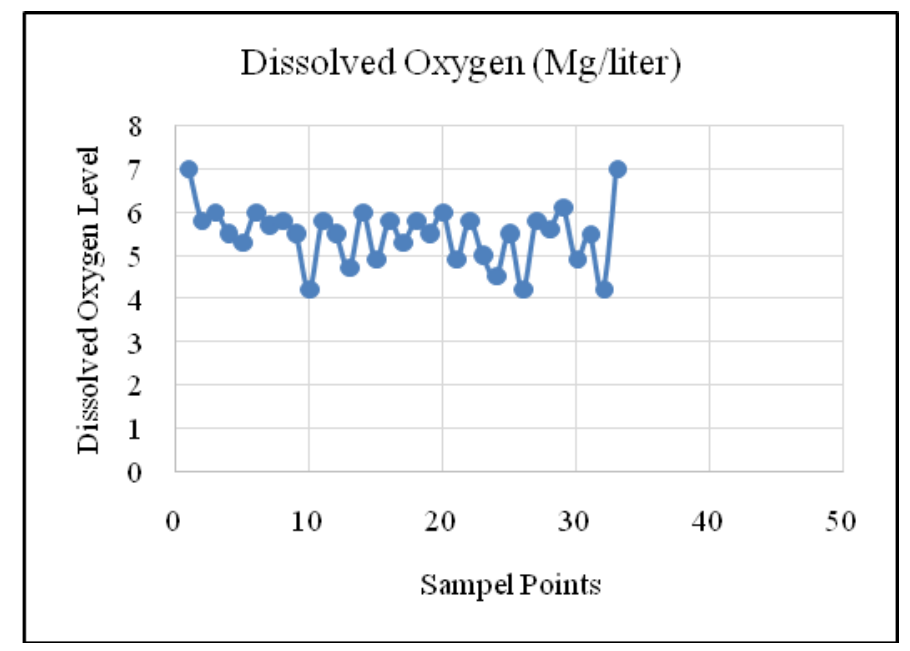

Fig. 5. Dissolved oxygen level in research location.

According to the Decree of the State Minister for the Environment (2004) dissolved oxygen levels for marine biota are $>5 \mathrm{mg} / \mathrm{liter}$. High or low levels of dissolved oxygen will affect the process of respiration in the marine ecosystem so that the survival of marine ecosystems (coral reefs) will turn to white rapidly and dead. The value of dissolved oxygen levels in this study is still following the level that can be tolerated by coral reefs. Water $\mathrm{pH}$ is the degree of acidity used to show the acidity and basicity of water. A good pH level for marine biota life (coral reefs) is 7-8.5 (Kepmen LH, 2004). In this study the minimum water $\mathrm{pH}$ was 6.7 , the maximum $\mathrm{pH}$ was 8.3 , and the average $\mathrm{pH}$ was 7.8 . For more details about the $\mathrm{pH}$ of the study, waters can be seen in Figure 6 below.

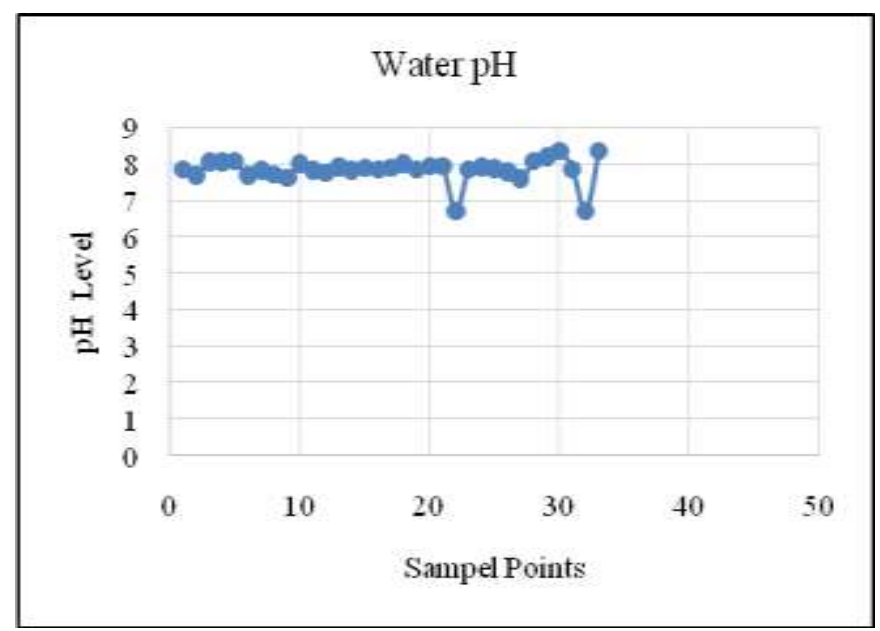

Fig. 6. $\mathrm{pH}$ water in the research location. 
$\mathrm{pH}$ has a role in influent the habitat's growth and activity in conducting interactions and respiration. The magnitude of the $\mathrm{pH}$ value in this study was very good, which was in neutral conditions and following conditions that can be tolerated for the survival of coral reefs. $\mathrm{pH}$ has a role in influent the development and activity of aquatic organisms in conducting metabolism and respiration. The magnitude of the $\mathrm{pH}$ value in this study was very good which is in neutral conditions and following conditions that can be tolerated for the survival of coral reefs. Salinity is the saltiness in a body of water. According to the Minister of Environment Decree (2004) the good level of salinity for coral reef life is between 33-34\%. The minimum salinity level in this study was $27.8 \%$ and the maximum was $37 \%$, while the average salinity level was $32,85 \%$. For more details, the level of salinity in this study can be seen in Figure 7 below.

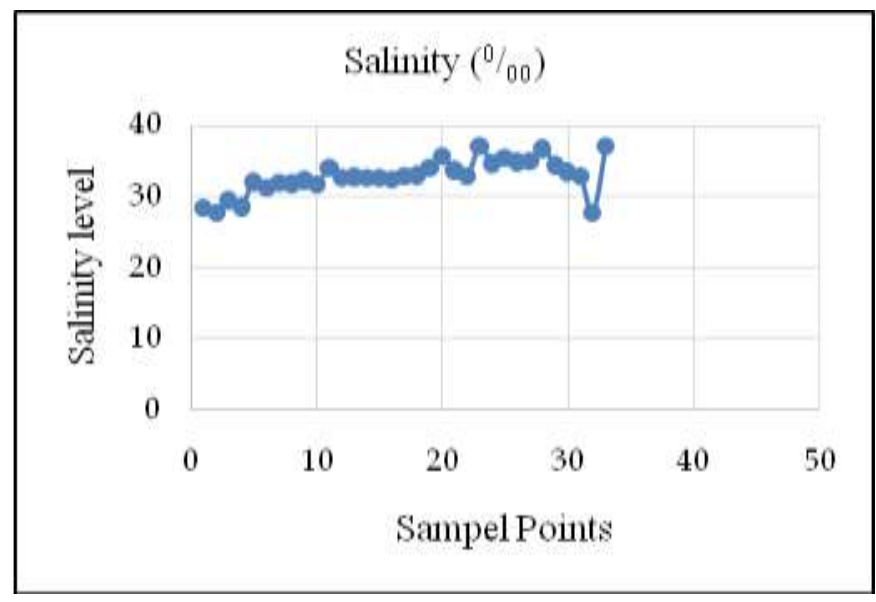

Fig. 7. Salinity level in research location.

According to Coral Watch (2009), salinity can change due to the increase and decrease of water molecules through the process of evaporation and rain. The level of salinity in each survey point of the research location has different conditions, this is due to several factors; the time and water conditions when sampling. High and low levels of salinity will affect the life of coral reefs in the process of photosynthesis.

\section{Conclusion}

This study provides an image accuracy of $42.50 \%$, further studies are needed to map the distribution and change of coral reefs in the coastal areas of Langsa City so that they will provide maximum results and can be used as a policy in the management of coral reef ecosystems. Sustainability factors of coral reefs at the research location showed different results. The water temperature was above the tolerance limit acceptable to coral reefs, which was higher than $40^{\circ} \mathrm{C}$, while dissolved oxygen levels, water $\mathrm{pH}$, and salinity are still at tolerances acceptable to coral reefs. 


\section{References}

[1] Dahuri, R., Rais, J., Ginting, S. P., \& Sitepu, M. J. (1996). Pengelolaan Sumber Daya Wilayah Pesisir dan Lautan Secara Terpadu. Jakarta: Pradnya Paramita.

[2] Effendi, H. (2003). Telaah kualitas air, bagi pengelolaan sumber daya dan lingkungan perairan. Kanisius

[3] Giyanto, A. M., Hadi, T. A., Budiyanto, A., Hafizt, M., Salatalohy, A., \& Iswari, M. Y. (2017). Status Terumbu Karang Indonesia 2017. Pusat Oseanografi-LIPI, Jakarta.

[4] Keputusan Menteri Negara Lingkungan Hidup Nomor 51. (2004). Baku Mutu Air Laut Untuk Biota Laut.

[5] Nybakken, J. W. (2001). Marine Biology: An Ecological Approach. $5^{\text {th }}$ ed. Benjamin Cummings, an Imprint of Addison Wesley Longman, Inc

[6] Rahmadi, M. T. (2018). Identifikasi Faktor-Faktor Yang Mempengaruhi Perubahan Habitat Bentik Di Sebagian Pulau Weh Tahun 2010 dan 2015. Publikauma: Jurnal Administrasi Publik Universitas Medan Area, 5(2), 1. DOI:10.31289/publika.v5i2.1427

[7] Reid, C., Marshall, N. J., Logan, D. and Kleine D. (2009) Coral Reefs and Climate Change; The guide for education and awareness. CoralWatch, The University of Queensland, Brisbane. 256 p ISBN 9780646523606

[8] Roelfsema, C., \& Phinn, S. (2009). A Manual for Conducting Georeferenced Photo Transects Surveys to Assess the Benthos of Coral Reef and Seagrass Habitats. Brisbane: University of Queensland.

[9] Sasmito, B., Sukmono, A., \& Bashit, N. (2018). Studi Perkembangan Terumbu Karang Di Perairan Pulau Panjang Jepara Menggunakan Citra Sentinel-2 Dengan Metode Algoritma Lyzenga (Doctoral dissertation, Universitas Dponegoro).

[10] Winarso, G. (2019). Metode Cepat Pemantauan Hutan Mangrove Menggunakan Data Penginderaan Jauh. Seminar Nasional Geomatika, 3, 901. doi:10.24895/sng.2018.30.1056 